\title{
Study of the Effects of Marble Powder Amount on the Self-Compacting Concretes Properties by Microstructure Analysis on Cement-Marble Powder Pastes
}

\author{
Rayed Alyousef $\mathbb{D}^{1},{ }^{1}$ Omrane Benjeddou $\mathbb{D}^{2,3}$ Mohamed Amine Khadimallah, ${ }^{1,4}$ \\ Abdeliazim Mustafa Mohamed, ${ }^{1}$ and Chokri Soussi ${ }^{1,2}$ \\ ${ }^{1}$ Prince Sattam Bin Abdulaziz University, College of Engineering, Civil Engineering Department, Alkharj, Saudi Arabia \\ ${ }^{2}$ Higher Institute of Technological Studies of Sfax, Department of Civil Engineering, Sfax, Tunisia \\ ${ }^{3}$ University of Tunis El Manar, National Engineering School of Tunis, Civil Engineering Laboratory, Tunis, Tunisia \\ ${ }^{4}$ University of Carthage, Polytechnic School of Tunisia, Laboratory of Systems and Applied Mechanics, Tunis, Tunisia
}

Correspondence should be addressed to Omrane Benjeddou; benjeddou.omrane@gmail.com

Received 7 July 2018; Accepted 9 September 2018; Published 27 September 2018

Academic Editor: Patrick W. C. Tang

Copyright (๑) 2018 Rayed Alyousef et al. This is an open access article distributed under the Creative Commons Attribution License, which permits unrestricted use, distribution, and reproduction in any medium, provided the original work is properly cited.

\begin{abstract}
The marble powder (MP), obtained from waste sludge marble processing, has a high specific surface area; this could mean that it can be used as filler added to self-compacting concrete (SCC). The aim of this experimental work is to study the effects of the cement-MP paste volume on the rheology in the fresh state and the hardened properties (compressive strength) of SCC by a microstructure analysis on paste samples with different amounts of MP. For all pastes, the morphological forms and the chemical composition of the main mineral components were analyzed by the scanning electron microscope (SEM) and X-ray diffraction (XRD). The hydration, microstructure, and mineralogical changes has been studied. Experimental results show that the cementMP paste volume has significant effects on the self-compacting and the self-leveling properties in the fresh state of SCC. In addition, the paste volume has a significant contribution on the compressive strength of SCC. Results indicate also that the difference in chemical composition between MP and cement have not any contribution on the paste volume effects.
\end{abstract}

\section{Introduction}

Marble is a metamorphic rock which results from the transformation of pure limestone. Chemically, calcite, dolomite, or serpentine materials are the major components of marble as crystalline rocks [1].

Marble waste can be recycled as a useful material. The most suitable inactivating method nowadays is recycling waste by producing new products or by addition as admixtures so that the environment is protected from waste deposits [2].

The results of several scientific works, studied the incorporation of marble waste into cement-based products such as normal concrete and high strength concrete [3-9], indicate an improvement in the compressive strength of concretes.
The use of cement in building materials is related especially to its hydration following the chemical reactions which form the hardened mass. This phenomenon allows predicting cement properties [10]. The chemical composition of hardened cement paste has a direct impact on the paste microstructure. That is why studying the mineral phase changes as well as the microstructure of maturing cement paste becomes a necessity to determine the strength of the crystalline lattice.

Generally, the most used techniques to determine the changes in the microstructure of cement pastes and concrete are the scanning electron microscopy (SEM) and the X-ray Diffraction (XRD) [10-16].

This experimental study aims to investigate the effects of the cement-MP paste volume on the fresh properties and on 
the compressive strength of SCC by a microstructure analysis.

The experimental program of this is composed mainly of three parts.

The first part consists of validating the use of marble, obtained from the waste sludge of marble cutting industry, as a filler added to cementitious matrix of SCC.

In the second part, we investigate the effects of the cement-MP paste volume on the rheology and on the compressive strength of SCC. For this purpose, five selfcompacting concrete specimens were prepared with various amounts of MP $(60,80,100$, and $120 \mathrm{~kg})$. For every fresh specimen, the slump flow test, L-box test, $\mathrm{V}$-funnel test, sieve stability test, bulk density test, and measuring the air content were performed.

In the last part of this work, we investigate a microstructure analysis on different pastes samples in order to more evaluate the effects of the paste volume on the SCC properties. In total, six samples are analyzed: two control pastes, one with cement and the other with marble powder; the four other samples were prepared by different amounts of MP (from 60 to $120 \mathrm{~kg}$ ) while keeping a constant cement amount.

\section{Materials and Methods}

\subsection{Materials}

2.1.1. Marble Powder. Marble powder was obtained by crushing marble sludge, which is a waste product from the marble cutting industry, was collected from locally situated marble cutting industries. The characterization of the MP was carried out using international experimental tests.

(1) Chemical Analysis. The chemical analysis, with an Atomic Absorption Spectrometry "AAS," was performed according to the requirements of EN ISO 15586. The results of the chemical analysis, presented in Table 1, indicate that the marble powder is excessively rich in calcite $\left(\mathrm{CaCO}_{3}=93.30 \%\right)$, and it is devoid of all clay and organic matter.

In addition, we measured the methylene blue value (MBV) according to the requirements of NF P 94-068. The test results demonstrated that the MBV of MP is about 0.45 and then the disorders in the fresh and hardened properties of the SCC were avoided owing to the existence of clay.

(2) Particle Size Analysis. Grain size distribution of MP was carried out according to the NF P 94-056 and NF P 94-057 standards. The particle size distribution curve, presented in Figure 1, indicates that the Hazen coefficient $(\mathrm{Cu})$ and the curvature coefficients (Cc) of MP are, respectively, equal to 6.33 and 0.43 . These values prove that the granular distribution of this powder is effectively graded.

(3) Physical Parameters. Table 2 presents the physical parameters of MP. The results indicate that the absolute density and the bulk density of the tested powder are $2.69 \mathrm{~g} / \mathrm{cm}^{3}$ and
$0.61 \mathrm{~g} / \mathrm{cm}^{3}$, respectively. In addition, its Blaine specific surface "BSS" value is equal to $9459 \mathrm{~cm}^{2} / \mathrm{g}$.

2.1.2. Cement. The chemical composition and the physical parameters of the used cement, CEM I 42.5, are presented, respectively, in Tables 3 and 4.

2.1.3. Aggregates. Natural sand $0 / 2$, crushed sand $2 / 4$, gravel $4 / 8$, and gravel $8 / 12$ were used in the preparation of the SCC specimens. The physical characteristics of these aggregates are displayed in Table 5.

\subsection{Formulation of a Self-Compacting Concrete with Marble} Sludge Powder. This part of our experimental investigation consists of evaluating the cement-MP paste volume effects on the fresh and the hardened properties of self-compacting concrete. For this purpose, we prepare four samples of selfcompacting concrete, SCC1, SCC2, SCC 3 and SCC4 by varying the MP amounts: 60, 80, 100, and $120 \mathrm{~kg}$.

The four SCCs were formulated based on the requirements of the Standard EN 206-1. They are an SCC30 of SF2 class (slump $=66-75 \mathrm{~cm}$ ) and 28-day compressive strength of $30 \mathrm{MPa}$. The cement dosage was set at $400 \mathrm{~kg}$, the weight ratio gravel/sand was set at $1(G / S=1)$, and the weight ratio water/equivalent cement was equal to 0.40 . The weight superplastifier (SP)/cement ratio was about $1.1 \%$. Table 6 presents the dosage of the four SCCs.

The volume of the paste was calculated by Equation (1) according to the excess paste method [17]:

$$
V_{\text {pâte }}=\frac{C}{\left(\rho_{\mathrm{abs}}\right)_{\mathrm{C}}}+\frac{F}{\left(\rho_{\mathrm{abs}}\right)_{\mathrm{MP}}}+\frac{E}{\rho_{\text {eau }}}+\frac{A}{\rho_{\mathrm{adj}}},
$$

where $\quad\left(\rho_{\mathrm{abs}}\right)_{\mathrm{C}}=3.08 \mathrm{~g} / \mathrm{cm}^{3}, \quad\left(\rho_{\mathrm{abs}}\right)_{\mathrm{MP}}=2.69 \mathrm{~g} / \mathrm{cm}^{3}$, and $\rho_{\mathrm{w}}=\rho_{\mathrm{ad}}=1 \mathrm{~g} / \mathrm{cm}^{3}$.

Figure 2 shows the paste volume according to the amount of MP. We note that this volume increases with the MP increases.

\section{Experimental Results}

3.1. Effects of Cement-MP Paste Volume on the Rheology of SCC in the Fresh State. The tests carried out on the four SCCs, presented in Figure 3, are the slump flow test, L-box test, $\mathrm{V}$-funnel test, sieve stability test, bulk density test, and measuring the air content.

3.1.1. Slump Flow Test. The results of this test, shown in Table 7, confirm that SCC1, SCC2, and SCC3 have a selfcompacting property because these slump flow values are from 42 to $71 \mathrm{~cm}$. The results show also that SCC4 cannot be considered as a self-compacting concrete because its slump flow value is indefinite. We remarked also that the slump flow value increases with the MP amount, and thereafter, the addition of a large amount of MP to self-compacting concrete increases its horizontal flow. This is due to the decrease in the viscosity of SCC when the cement-MP 
TABLE 1: Chemical composition of marble powder.

\begin{tabular}{lccccccccccc}
\hline Component & $\mathrm{CaCO}_{3}$ & LOI & $\mathrm{Ca}$ & $\mathrm{CaO}$ & $\mathrm{MgO}$ & $\mathrm{SiO}_{2}$ & $\mathrm{Fe}_{2} \mathrm{O}_{3}$ & $\mathrm{Al}_{2} \mathrm{O}_{3}$ & $\mathrm{MgCO}_{3}$ & Sulfur (S) & $\mathrm{Moisture}$ \\
\hline Percentage & 93.30 & 42.60 & 37.36 & 52.28 & 0.50 & 3.00 & 0.39 & 0.14 & 1.04 & 0.03 & 0.20
\end{tabular}

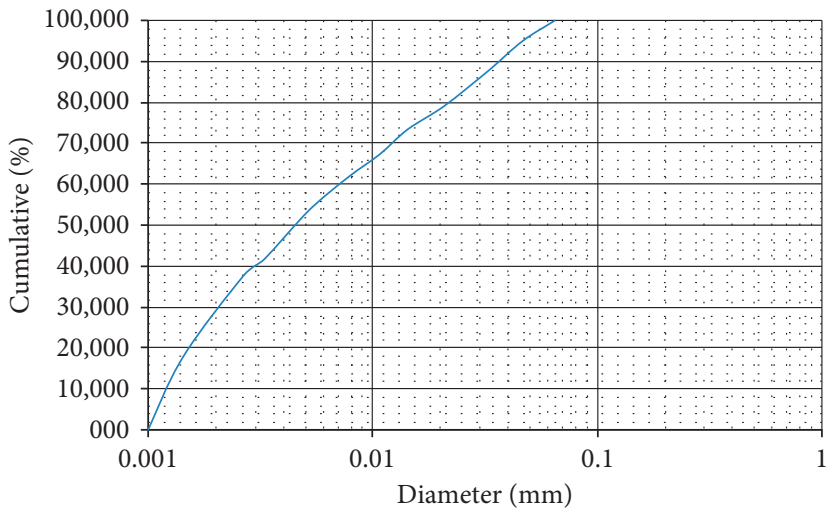

Figure 1: Particle size distribution curve of MP.

TABle 2: Physical parameters of MP.

\begin{tabular}{lcccc}
\hline Properties & Particle size $(\mathrm{mm})$ & Absolute density $\left(\mathrm{g} / \mathrm{cm}^{3}\right)$ & Bulk density $\left(\mathrm{g} / \mathrm{cm}^{3}\right)$ & Blaine specific surface $(\mathrm{BSS})(\mathrm{cm} / \mathrm{g})$ \\
\hline Value & $0 / 0.063$ & 2.69 & 0.61 & 9459 \\
\hline
\end{tabular}

TAble 3: Chemical composition of cement.

\begin{tabular}{llllccccccc}
\hline Component & $\mathrm{CaO}$ & $\mathrm{SiO}_{2}$ & $\mathrm{LOI}$ & $\mathrm{K}_{2} \mathrm{O}$ & $\mathrm{MgO}$ & $\mathrm{Fe}_{2} \mathrm{O}_{3}$ & $\mathrm{Al}_{2} \mathrm{O}_{3}$ & $\mathrm{RI}$ & $\mathrm{SO}_{3}$ \\
\hline Percentage & 63.53 & 20.19 & 3.21 & 0.46 & 1.07 & 3.75 & 4.92 & 0.61 & 1.57 \\
\hline
\end{tabular}

TABle 4: Physical and mechanical properties of cement.

\begin{tabular}{lcccc}
\hline Properties & Absolute density $\left(\mathrm{g} / \mathrm{cm}^{3}\right)$ & Bulk density $\left(\mathrm{g} / \mathrm{cm}^{3}\right)$ & BSS $\left(\mathrm{cm}^{2} / \mathrm{g}\right)$ & True class of strength $(\mathrm{MPa})$ \\
\hline Value & 3.08 & 1.03 & 3100 & 44.5 \\
\hline
\end{tabular}

TABLE 5: Physical characteristics of aggregates.

\begin{tabular}{|c|c|c|c|c|c|c|c|}
\hline Aggregates & $\begin{array}{l}\text { Absolute density } \\
\left(\mathrm{g} / \mathrm{cm}^{3}\right)\end{array}$ & $\begin{array}{l}\text { Bulk density } \\
\left(\mathrm{g} / \mathrm{cm}^{3}\right)\end{array}$ & $\begin{array}{l}\text { Finesse } \\
\text { module }\end{array}$ & $\begin{array}{c}\text { Equivalent of sand } \\
(\%)\end{array}$ & $\begin{array}{c}\text { Los Angeles } \\
(\%)\end{array}$ & $\begin{array}{c}\mathrm{MDE} \\
(\%)\end{array}$ & $\begin{array}{c}\text { Absorption } \\
(\%)\end{array}$ \\
\hline Sand $0 / 2$ & 2.42 & 1.47 & 1.85 & 91 & - & - & - \\
\hline $\begin{array}{l}\text { Crushed sand } \\
2 / 4\end{array}$ & 2.55 & 1.32 & 4.8 & 100 & 17 & 13 & 0.32 \\
\hline Gravel 4/8 & 2.55 & 1.42 & - & - & 17 & 13 & 0.32 \\
\hline Gravel 8/12 & 2.55 & 1.40 & - & - & 17 & 13 & 0.32 \\
\hline
\end{tabular}

TABLE 6: Composition of the different SCCs.

\begin{tabular}{lcccc}
\hline & SCC1 & SCC2 & SCC3 & SCC4 \\
\hline Cement $(\mathrm{kg})$ & 400 & 400 & 400 & 400 \\
Marble powder $(\mathrm{kg})$ & 60 & 80 & 100 & 120 \\
Gravel 8/12 $(\mathrm{kg})$ & 720 & 720 & 720 & 720 \\
Gravel 4/8 $(\mathrm{kg})$ & 180 & 180 & 180 & 180 \\
Sand 0/2 (kg) & 720 & 720 & 720 & 720 \\
Sand 2/4 (kg) & 180 & 180 & 180 & 180 \\
Water (l) & 184 & 192 & 200 & 208 \\
SP (kg) & 4.4 & 4.4 & 4.4 & 4.4 \\
Paste volume $\left(\mathrm{m}^{3}\right)$ & 0.340 & 0.355 & 0.371 & 0.386 \\
\hline
\end{tabular}

paste volume increase. It can be concluded that the addition of different amounts of MP to the cementitious matrix of self-compacting concrete affects the horizontal flow of the SCC.

3.1.2. V-Funnel Test. For the flow class SF2, the flow time must be between 8 and 14 seconds. According to NF EN 12350-9 requirements, nonuniform flow of concrete from the funnel suggests a lack of segregation resistance. V-funnel results were related to many parameters such as concrete viscosity, passing ability, and segregation resistance. 


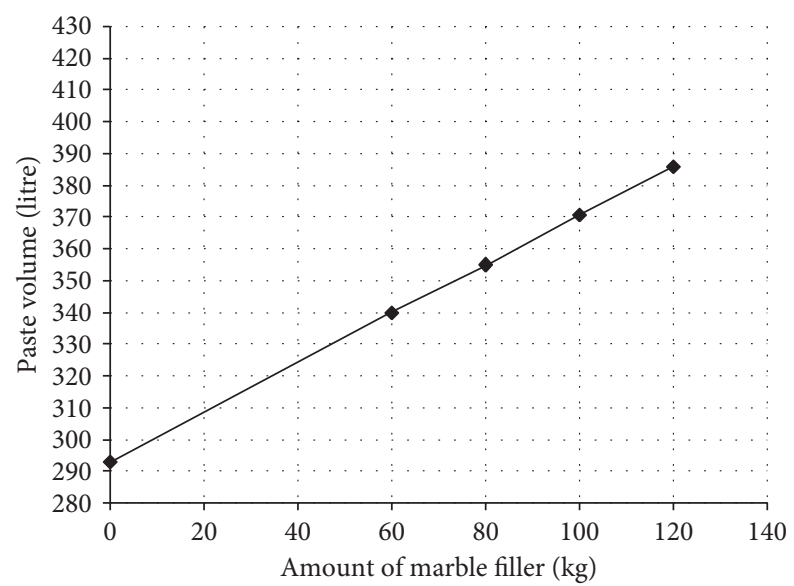

Figure 2: Volume of the paste according to the amount of MP.

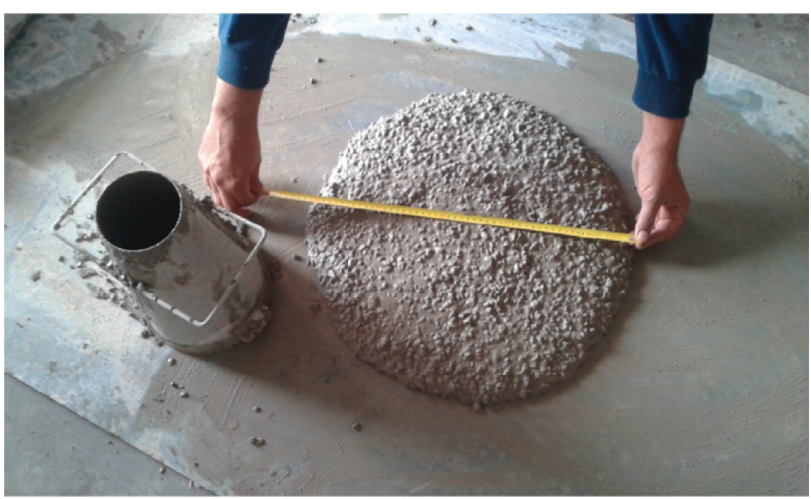

(a)

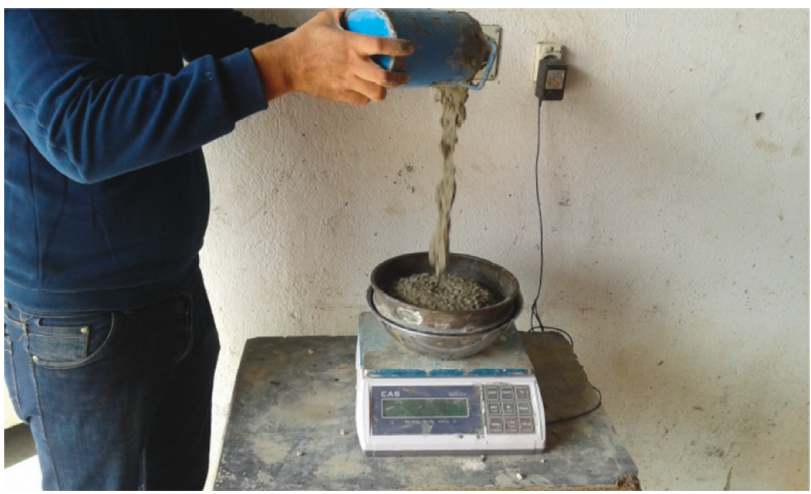

(c)

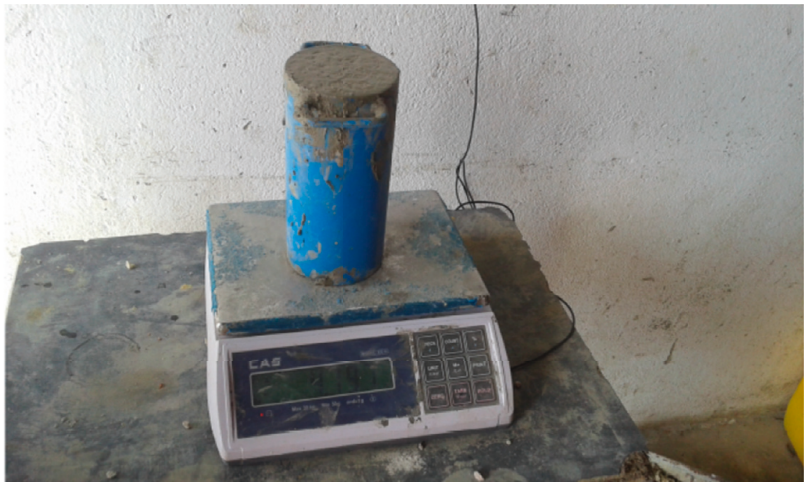

(e)

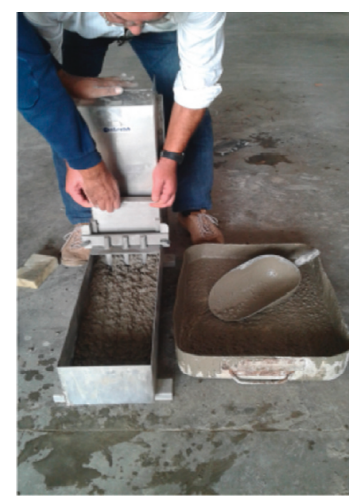

(b)

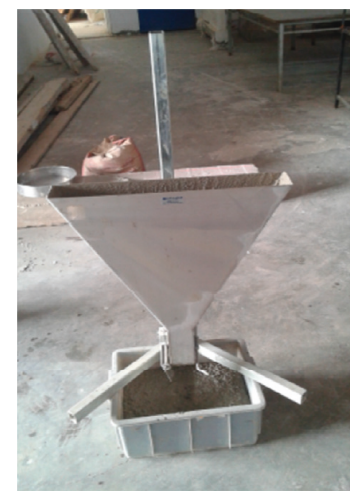

(d)

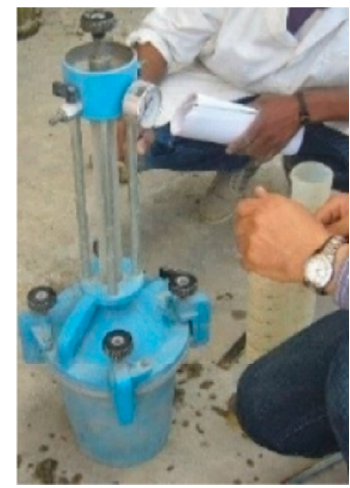

(f)

FIGURE 3: Test on the four SCCs in the fresh state. (a) Slump flow test. (b) L-box test. (c) Sieve stability test. (d) V-funnel test. (e) Bulk density. (f) Air content test. 
TABle 7: Properties of the four SCCs in fresh state.

\begin{tabular}{|c|c|c|c|c|c|}
\hline Test & Standards value for SF2 & SCC1 & SCC2 & SCC3 & SCC4 \\
\hline Slump flow $(\mathrm{cm})$ & 66 à $75 \mathrm{~cm}$ & 42 & 58 & 71 & Indefinite \\
\hline L-box & $\mathrm{h} 2 / \mathrm{h} 1 \geq 0.8$ & 0.43 & 0.59 & 0.85 & 0.99 \\
\hline Sieve stability (\%) & $<15 \%$ & 1.94 & 2.50 & 3.61 & 5.22 \\
\hline Bulk density $\left(\mathrm{kg} / \mathrm{m}^{3}\right)$ & - & 2.439 & 2. 461 & 2. 482 & 2. 501 \\
\hline V-funnel & $8 \leq$ time $\leq 14 \mathrm{~s}$ & $9.29 \mathrm{~s}$ & $6.48 \mathrm{~s}$ & $4.33 \mathrm{~s}$ & $2.59 \mathrm{~s}$ \\
\hline Air content $(\%)$ & $\leq 5 \%$ & 4.2 & 3.4 & 2.2 & 1.2 \\
\hline
\end{tabular}

Therefore, the true cause of a slow flow time cannot be identified by the test results [18].

According to the results presented in Table 7, the slump flow values of the four SCC samples vary from $9.29 \mathrm{~s}$, for SCC1, to $2.59 \mathrm{~s}$, for SCC4. We can conclude that the flow time value decreases with the MP amount increase, and thereafter, the addition of a large amount of MP to selfcompacting concrete increases its vertical flow. This is due to the increase in the fresh density of SCC when the amount of MP increases. For example, the density is equal to $2.439 \mathrm{~kg} / \mathrm{m}^{3}$ for SCC1 and $2.501 \mathrm{~kg} / \mathrm{m}^{3}$ for SCC 4 .

To confirm the last result, we measure the flow times, by Marsh cone, of four paste samples prepared by varying the MP amount. The results, presented in Figure 4, show that the flow times of the pastes, with a large amounts of MP, are the faster. Finally, these results confirm the result that the flow time of SCC decreases with the paste volume. Also, we can conclude that the self-leveling property of the SCC in the fresh state was ameliorated when increasing the paste volume.

3.1.3. L-Box Test. The L-Box test is used to investigate the flow rate and passing ability of SCC in confined spaces, thus quantifying the suitability of the SCC for use in a member with congested reinforcement. From the results presented in Table 7 it is clear that the paste volume has a big impact on the $\mathrm{H} 2 / \mathrm{H} 1$ blocking ratio of SCC. However, the blocking ratio of $\mathrm{H} 2 / \mathrm{H} 1$ increases with the increase of the cement-MP paste volume. For this test, the increases in the blocking ratio observed, when compared SCC1 to SCC3 and SCC1 to SCC4, are approximately $100 \%$ and $130 \%$, respectively (Table 3). This result is a consequence of the decrease in the viscosity of SCC with large amount of MP (a high paste volume).

The results show also that only the two concretes SCC3 and SCC4 have a good passing ability because their blocking ratio are bigger than the passing ability tolerance of 0.80 .

3.1.4. Sieve Stability Test. The results presented in Table 7 show that the sieve stability percentages of the four SCCs are less than 15\% (NF EN 12350-11). Indeed, the four formulated SCCs have a high resistance to segregation. This is due to the fine particles sizes of MP that avoid this phenomenon. The results show also that the resistance to segregation of

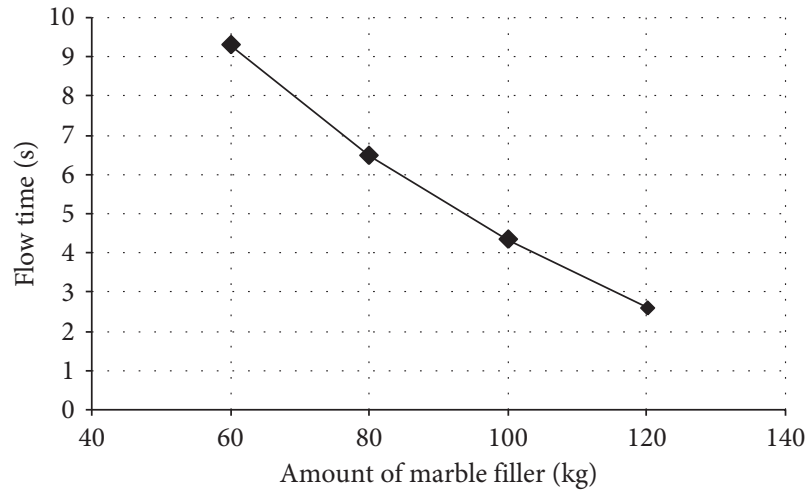

FIgURE 4: Flow time value as function of MP amount.

self-compacting concrete decreases when we increase the paste volume.

3.1.5. Air Content Test. The percentage of air content should not exceed $5 \%$ for a self-compacting concrete. The air content test is required to check air-entrained concrete.

The results of the air content measure, presented in Table 7, show that the four formulated SCCs have an air content percentage varying from $1.2 \%$ to $3.2 \%$. These values prove that the four SCCs have maximum compactness without vibration or clamping (air content $\leq 5 \%$ ). The results show also that the compactness of self-compacting concrete increases when we increase the paste volume.

\subsection{Effect of Cement-MP Paste Volume on the Compressive} Strength of SCC. The effect of the MP amount on the compressive strength of self-compacting concrete is studied. For this, 18 cylindrical specimens $16 \times 32 \mathrm{~cm}$ were prepared for each SCC (Table 8). The specimens were crushed at the ages of 3 days, 7 days, 14 days, and 28 days (Figure 5).

Compressive strength values of the four tested concretes SCC1, SCC2, SCC3, and SCC4 are very close either at a young age and middle age. The compressive strengths at the age of 28 days, of SCC2 and SCC 3 (MP amounts respectively equal to 80 and $100 \mathrm{~kg}$ ), are greater than the resistance of $30 \mathrm{MPa}$ desired.

The results show that the paste volume has a significant effect on the compressive strengths of SCC on young and middle ages. Indeed, the compressive strengths increase with the cement-MP paste volume at any age. This is due to the 
TABLE 8: Compressive strength of the four SCC at different ages.

\begin{tabular}{lcccc}
\hline \multirow{2}{*}{ Type of concrete } & \multicolumn{3}{c}{ Compressive strength (MPa) } \\
& 3 days & 7 days & 14 days & 28 days \\
\hline SCC1 & 13 & 17 & 23 & 32 \\
SCC2 & 15 & 19 & 33 & 39 \\
SCC3 & 16 & 21 & 19 & 41 \\
SCC4 & 11 & 16 & 25 \\
\hline
\end{tabular}

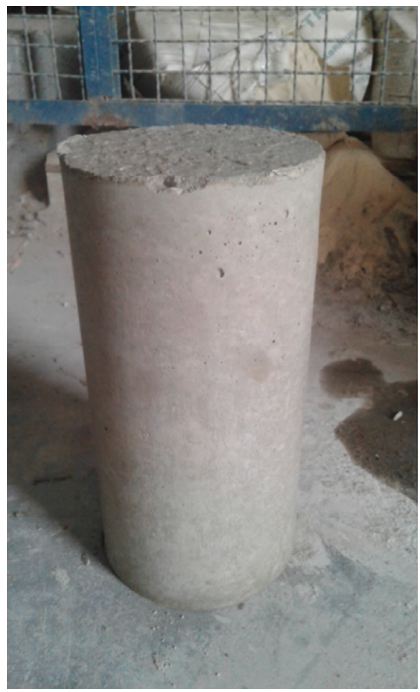

(a)

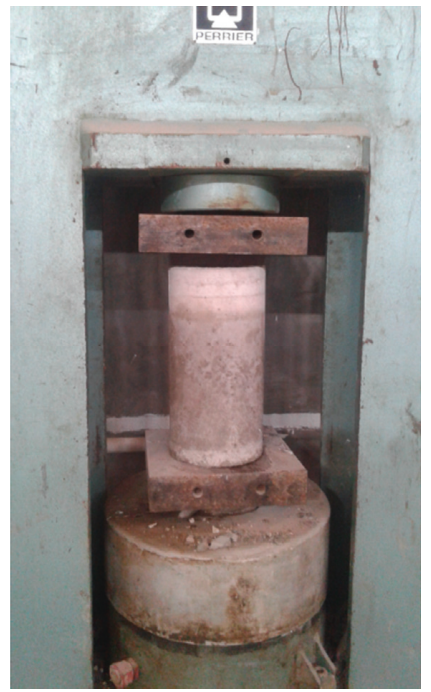

(b)

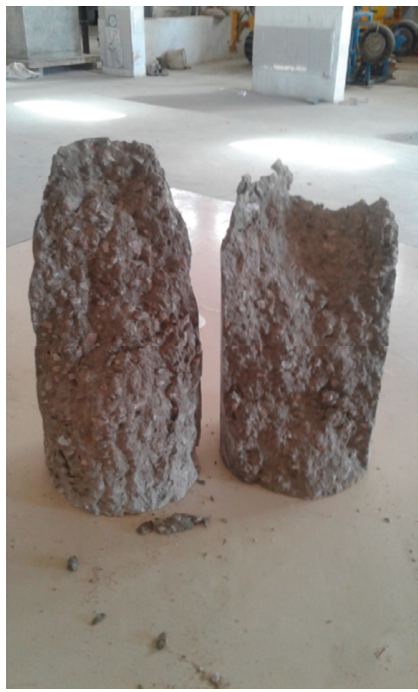

(c)

Figure 5: Compressive strength test.

decrease of the air content of SCC and to the higher compactness provided by the higher paste volume.

\section{Discussions by Microstructure Analysis}

Microstructure analysis is made to understand better the behavior of the different pastes and their performances. Indeed, for more discussions of the experimental results about the effects of the cement-MP paste volume on the SCC properties in the fresh and in the hardened state, a microstructure analysis were make on two control pastes and on the four cement-marble powder pastes of the four tested concretes. The first control paste was made by $400 \mathrm{~kg}$ of cement and the second by $400 \mathrm{~kg}$ of MP. The other, denoted CMP1, CMP2, CMP3, and CMP4, were prepared with $400 \mathrm{~kg}$ of cement and different amounts of MP respectively equal to $60,80,100$, and $120 \mathrm{~kg}$. The weight cement/water ratio was 0.26 . The compositions of the six pastes are presented in Table 9.

Scanning electron microscope (SEM) allows to observe the morphological forms and the chemical composition of the main mineral components (Figure 6).

4.1. Microstructure Analysis on Cement Paste. Scanning electron microscopy (SEM) micrographs and energy-dispersive
X-ray spectroscopy (XRD) patterns of cement paste at 28 days are shown in Figure 7.

Figure 7 shows that the hydrating in time of this paste is composed mainly of hydrated silicates of calcium (CSH) phase accompanied with a calcium hydroxide (portlandite) and hydration products of calcium aluminate (ettringite).

In addition, the hydrating process is composed of two main steps. In the first step and after a few hours of the paste mixing, the hydrolysis of tricalcium (C3S) and dicalcium (C2S) silicates forms the portlandite that will be separated $[14,15]$. According to the SEM micrograph presented in Figure 7, the obtained portlandite creates massive, hexagonal crystals.

In the second step of the process of hydration of cement paste, the first forms of hydrated calcium silicates (CSH) are created. For hardening cement paste, $\mathrm{CSH}$, with varying degrees of crystallization and differential alkalinity, is the main component and the most important factor affecting the mechanical strength. In addition, the hydration and hardening mechanisms of cement is based on CSH density combined with the addition of water and crystallization of ettringite and calcium hydroxide intergrowths which form pores in hardening cement paste $[14,15]$.

Finally, the mechanical strength of hardened cement paste depends on chemical and mineral composition, and it has a direct impact on the structure that determines the tightness of mass and the strength of the crystalline lattice. 
TABLE 9: Composition of the different pastes mixes.

\begin{tabular}{lcccccc}
\hline Pastes & Cement paste & Marble paste & CMP1 & CMP2 & CMP3 & CMP4 \\
\hline Cement $(\mathrm{kg})$ & 400 & 0 & 400 & 400 & 400 & 400 \\
Marble powder $(\mathrm{kg})$ & 0 & 400 & 60 & 80 & 100 & 120 \\
\hline
\end{tabular}

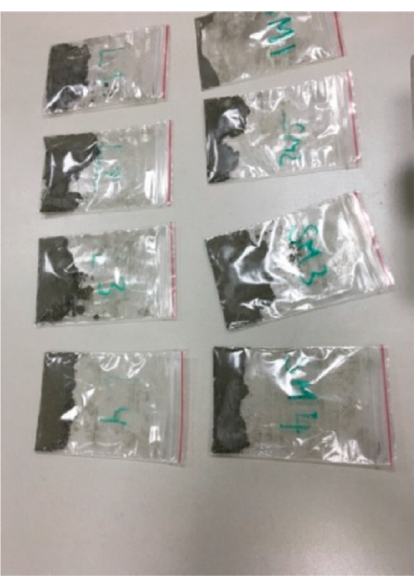

(a)

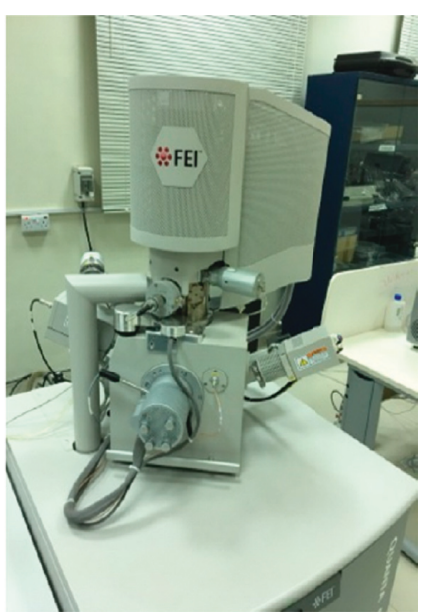

(d)

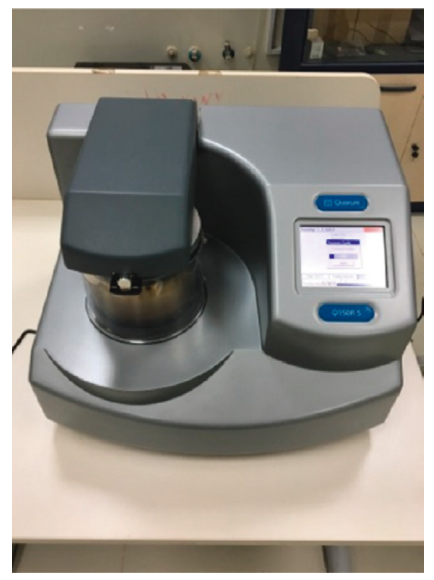

(b)

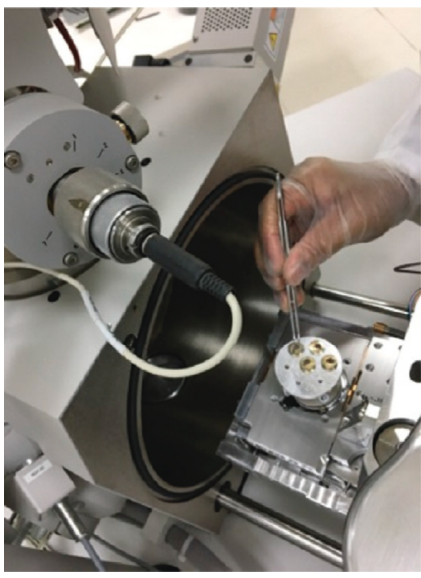

(c)

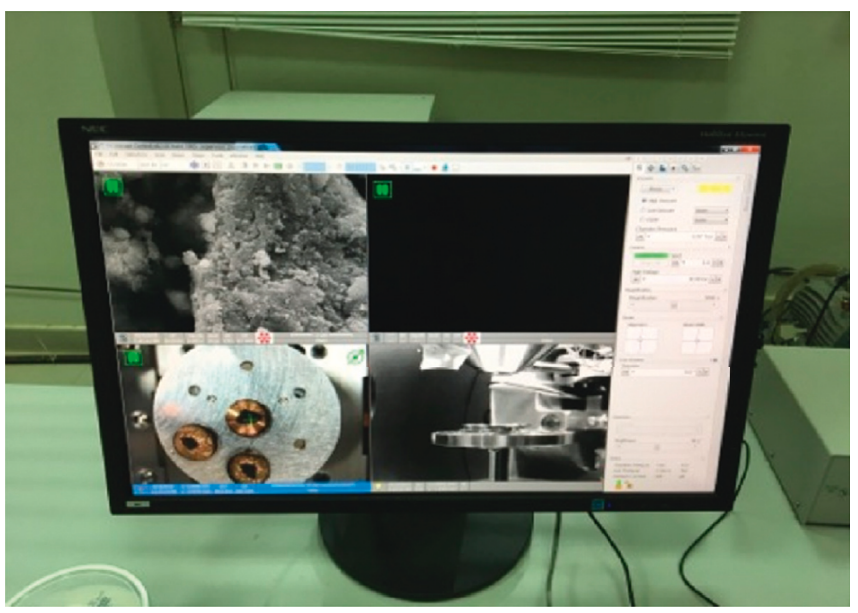

(e)

FIgURE 6: The scanning electron microscope (SEM).

4.2. Microstructure Analysis on Marble Powder Paste. SEM image and XRD pattern of marble paste at 28 days are presented in Figure 8. According to the chemical analysis presented in Table 1, the major component of MP is the calcium oxide and the minor contents are $\mathrm{SiO}_{2}, \mathrm{MgO}, \mathrm{Al}_{2} \mathrm{O}_{3}$, and $\mathrm{Fe}_{2} \mathrm{O}_{3}$, indicating its of carbonate nature. XRD pattern of MP paste, presented in Figure 8, shows that as expected, calcite is the main crystalline mineral in MP (with significant peaks) and quartz is also identified in very low concentration.

In addition, according to the results of Table 1 and SEM image of MP crystals (Figure 8), it is clear that MP does not possess any pozzolanic activity. It will act as an inert and filler material rather than a pozzolanic one [8].

To confirm this last result, the hydraulic properties of MP were verified. For this, we measured the temperature evolution of MP paste. From the result, illustrated in Figure 9, we can remark that the temperature of the paste should be adjusted very slightly (from 18 to $20^{\circ} \mathrm{C}$ ) for a period of more than $6 \mathrm{~h}$. This result indicates that the MP exhibits no hydraulic property in the presence of water, and we can therefore consider the MP as inert component in concrete. In fact, the hydraulic reaction of SCC will not be modified or influenced.

4.3. Microstructure Analysis on Cement-Marble Powder Pastes. According to SEM micrograph of cement paste (Figure 7) and the SEM micrographs of the pastes CMP1, CMP, CMP3, and CMP4 (Figure 10), it was observed that cement-marble powder paste specimens are denser and less porous than cement paste specimen. At this age, the microstructure of pastes is composed of amorphous particles of calcium silicate hydrate $(\mathrm{CSH})$ and calcium hydroxide $(\mathrm{CH})$ crystals that appear in massive layers. Ettringite (E) needles 


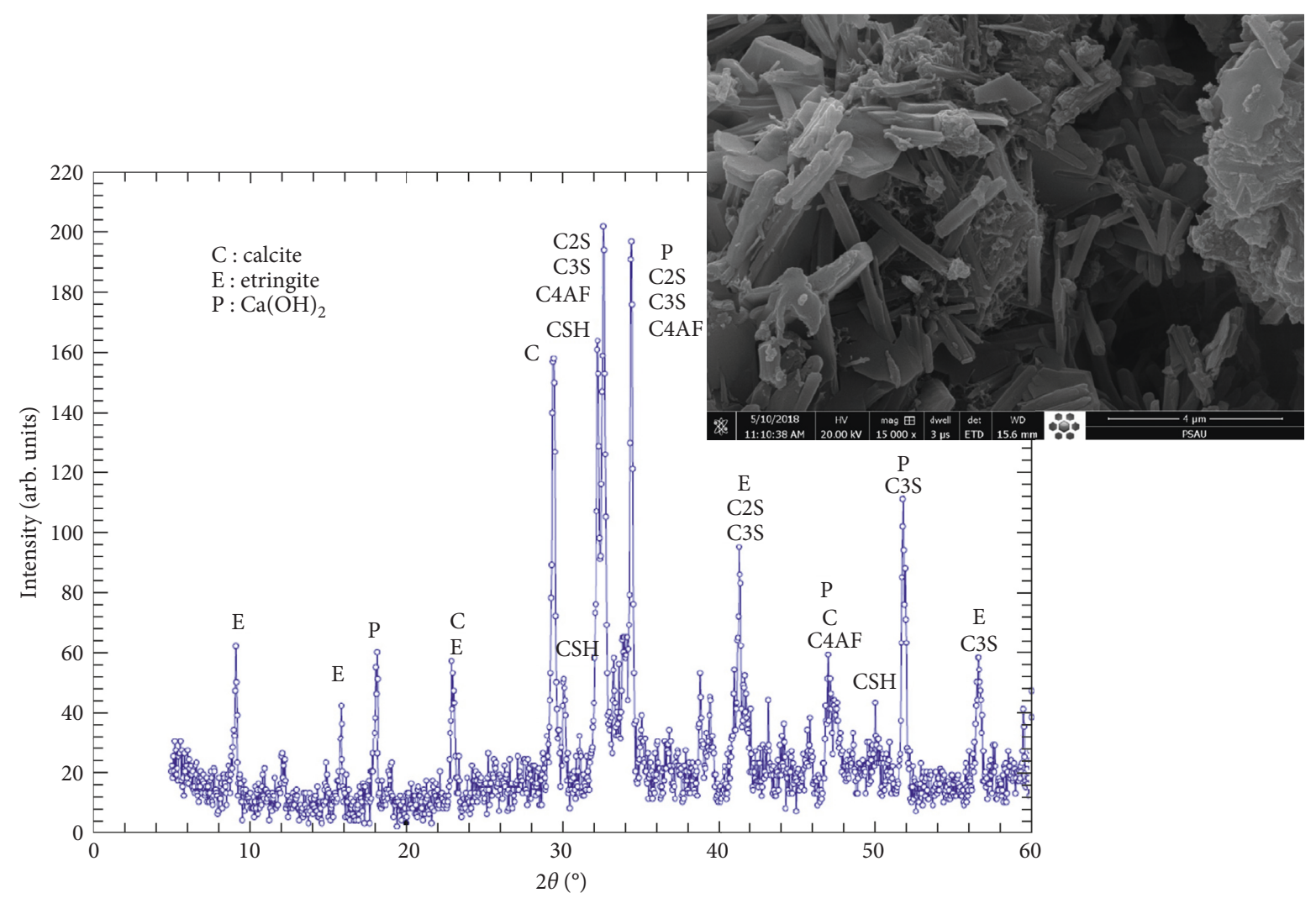

FIgURE 7: SEM micrographs and XRD pattern of cement paste.

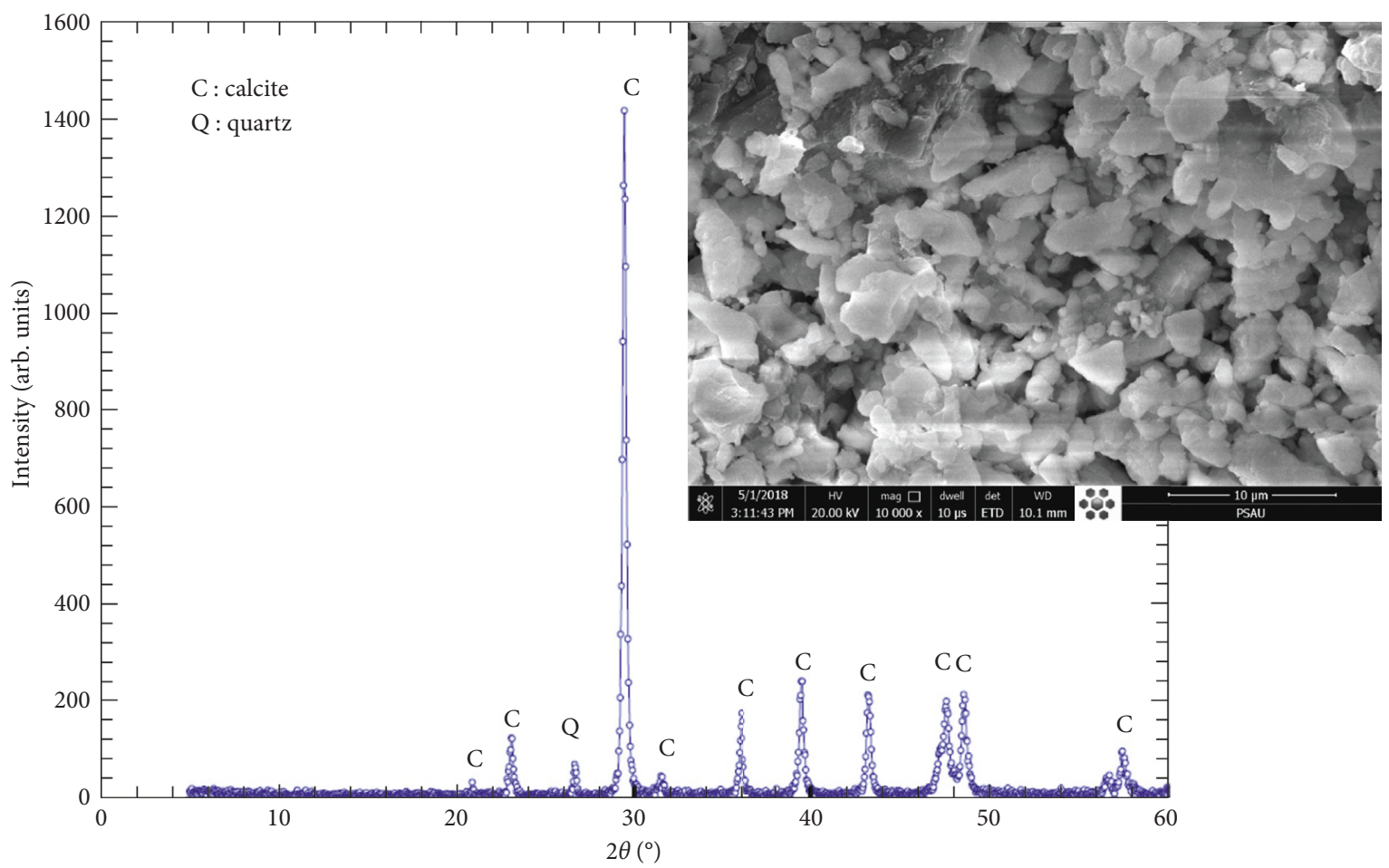

FIgURE 8: SEM micrographs and XRD patterns of marble powder paste. 


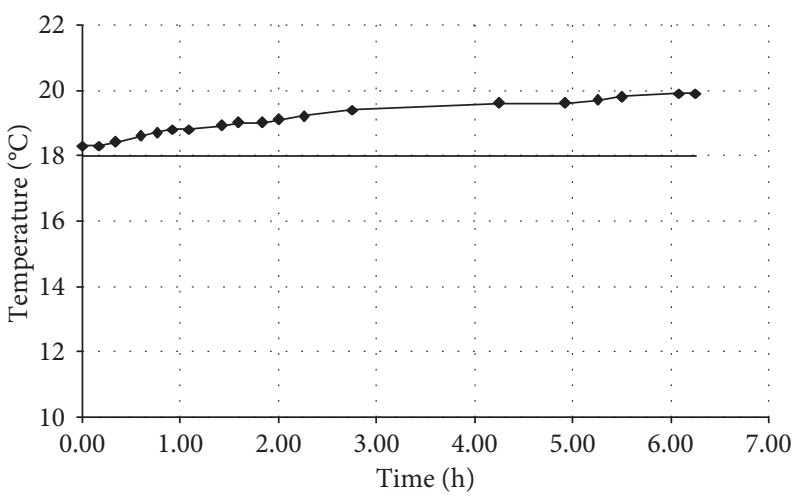

FIgURE 9: MP paste temperature measurement.

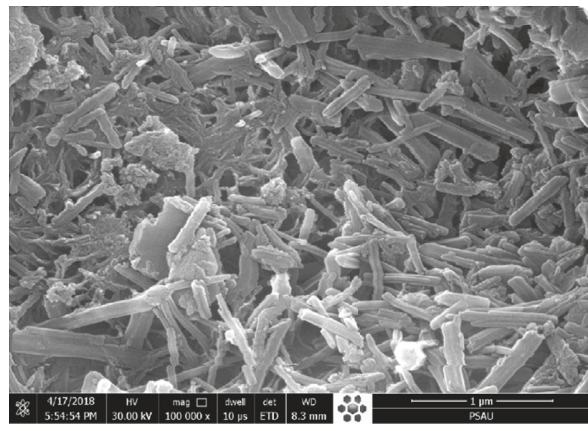

(a)

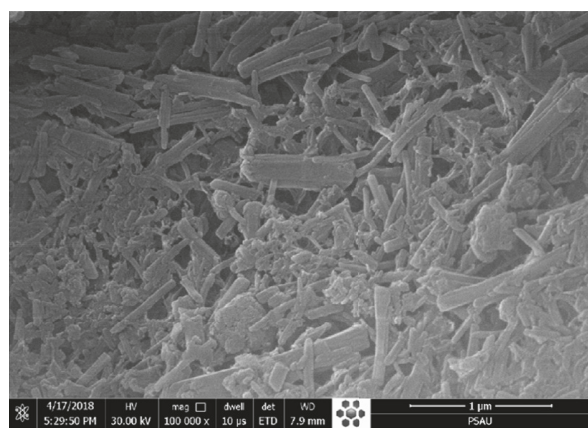

(c)

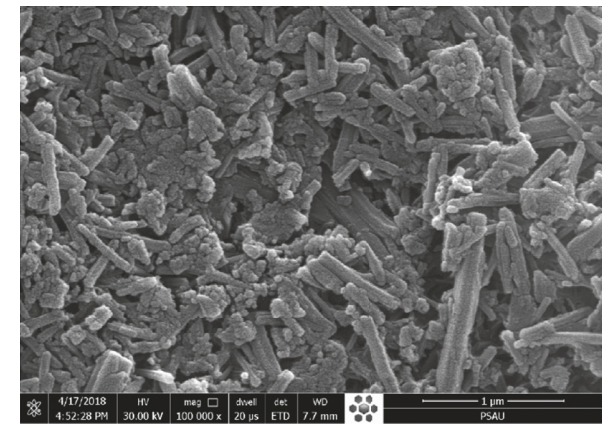

(b)

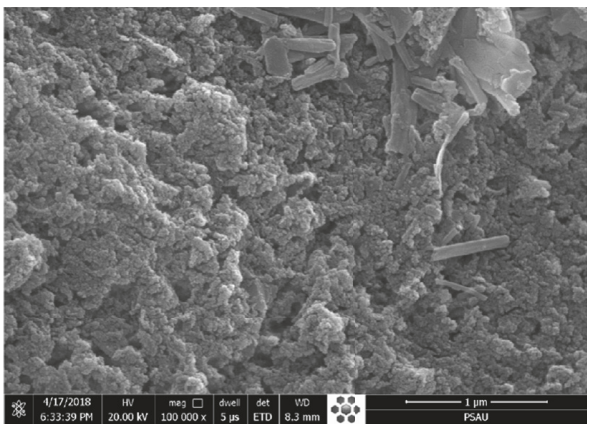

(d)

Figure 10: SEM micrographs for cement-marble powder paste: (a) CMP1, (b) CMP2, (c) CMP3, and (d) CMP4.

are located in pores, and then the paste is totally hydrated and all voids were completely filled. Thereafter, when used more MP amount, the obtained SCC is more dense and less porous. This conclusion confirms the obtained experimental results of the bulk densities and the air content percentages of the four tested SCC (Table 7).

The comparison between cement paste and cement pastes with different amounts of marble powder indicates that there is no remarkable difference between specimens, especially regarding calcium hydroxide $(\mathrm{CH})$ contents as seen in Figures 11-14. Also, we observed that there was no change in the phase composition qualitatively when incorporating marble powder in cement paste. It clearly indicates that marble powder is an inert material and does not lead to much change in the phase composition of the resultant mix.
On the other hand, the same portlandite peak is observed for cement paste and for cement-marble powder pastes. In addition, the presence of ettringite, which is very fine needles, is less for the cement pastes containing marble powder. This is certainly due to the high compactness of these pastes compared with that of cement alone.

According to the SEM image of cement paste presented in Figure 7, we remarked that the microstructure of this paste is highly porous with irregular micropores in cement matrix. This can explain the poor self-compaction property of the ordinary concrete. In addition, the interpretation of the SEM images of the four pastes with MP powder shows that when adding a high amount of MP, the microstructure of the obtained paste is less porous and the amount of large pores in the bulk matrix is also reduced. These results indicate the 


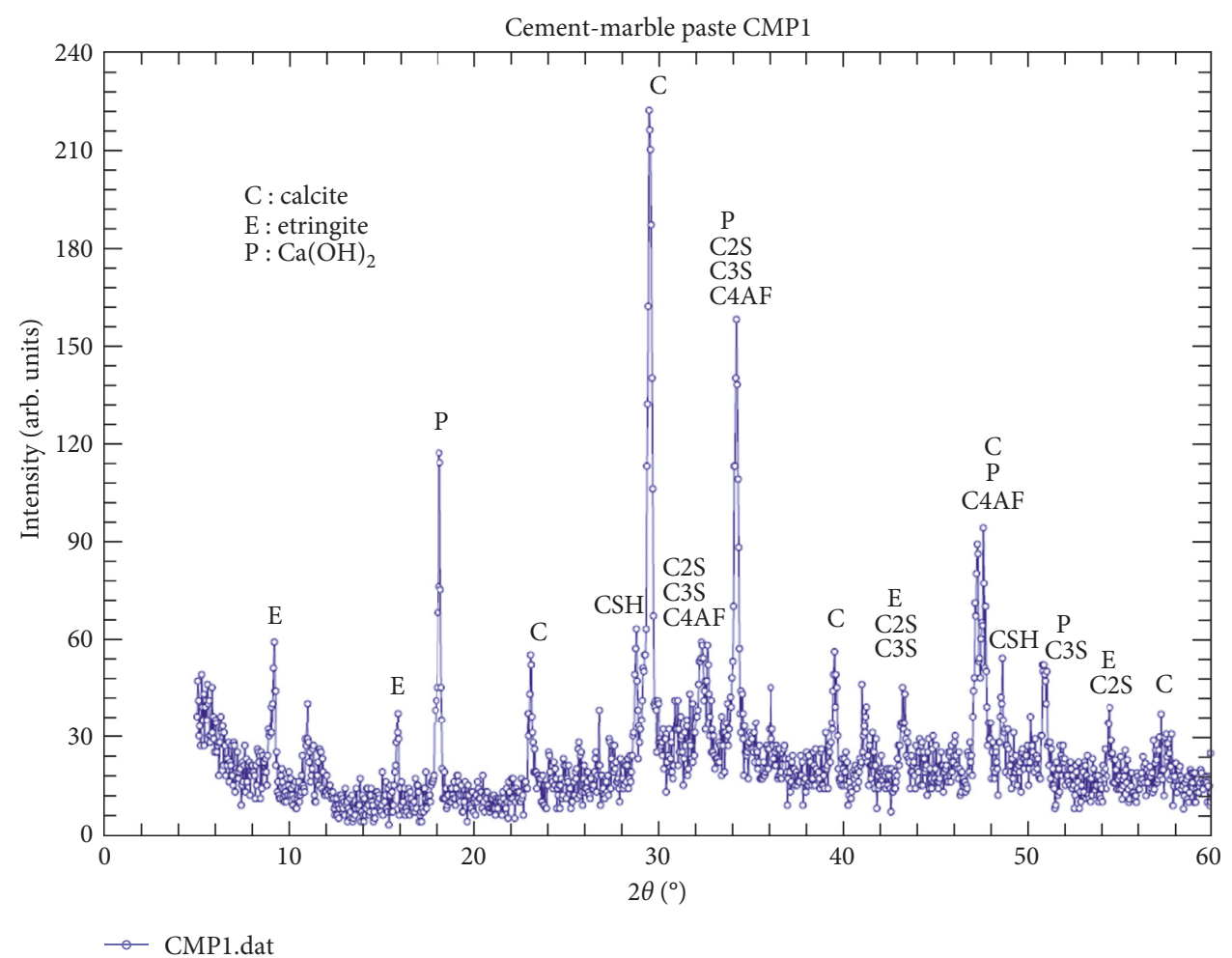

FIgURE 11: X-ray diffraction pattern of paste CMP1.

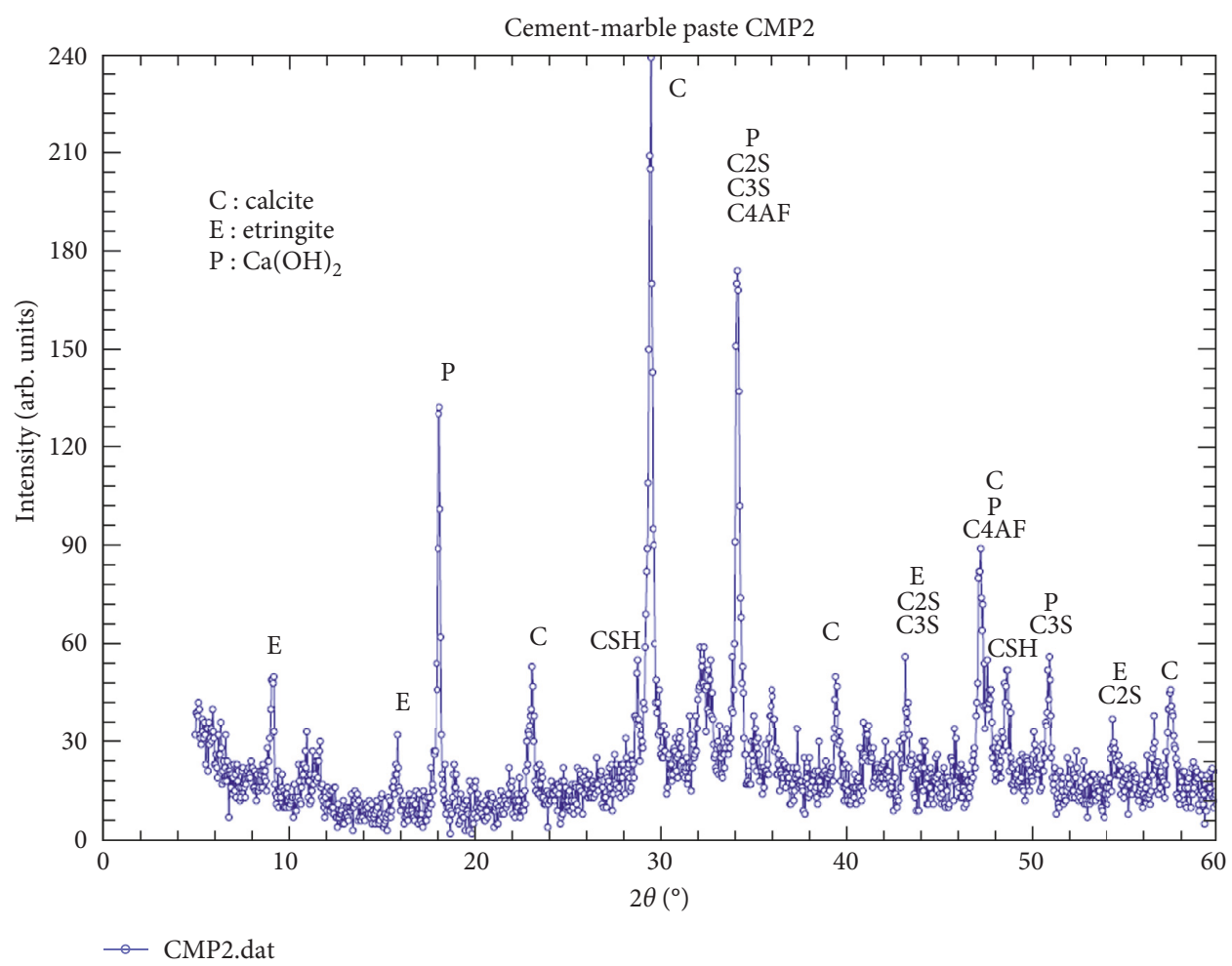

FIgURE 12: X-ray diffraction pattern of paste CMP2. 


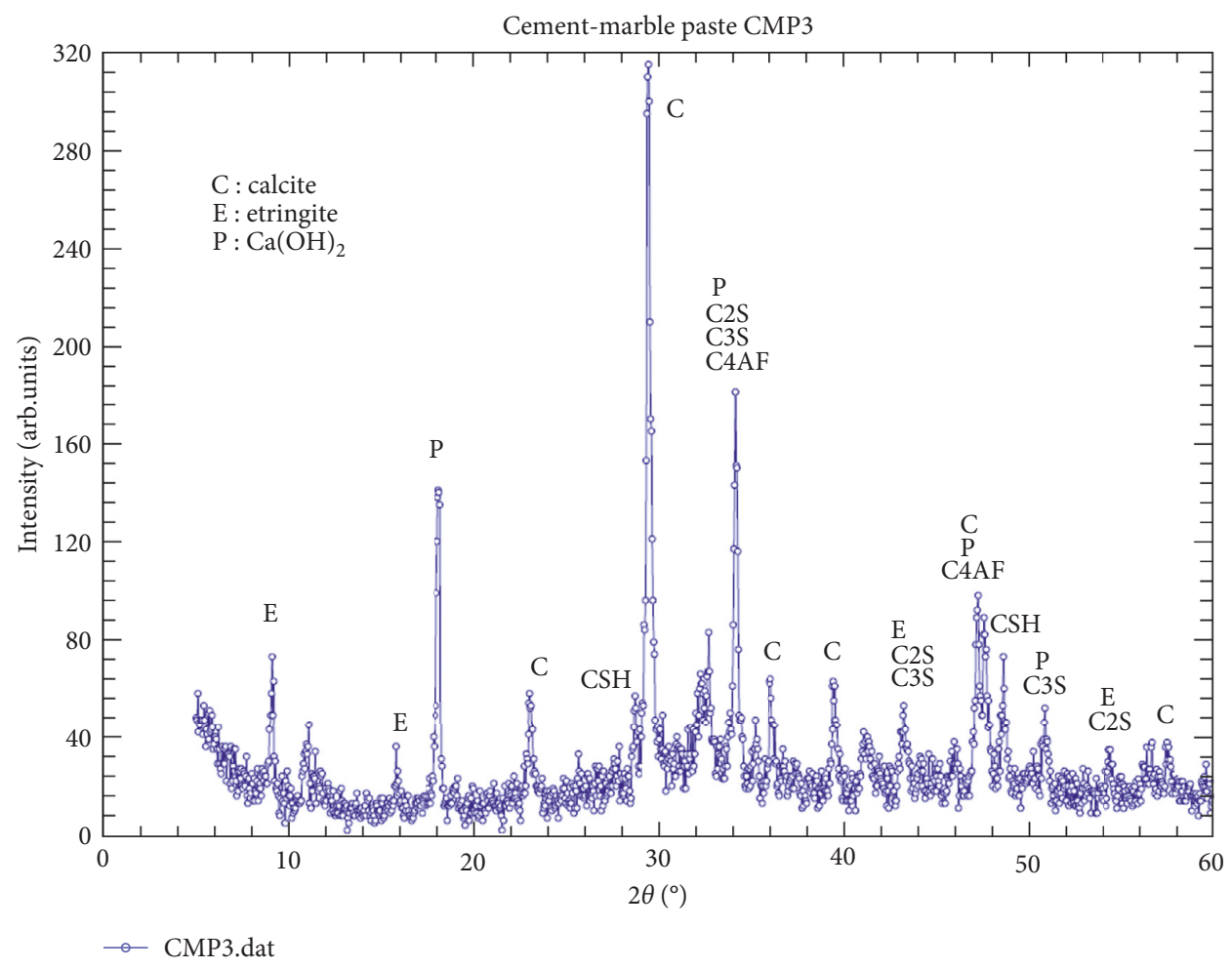

Figure 13: X-ray diffraction pattern of paste CMP3.

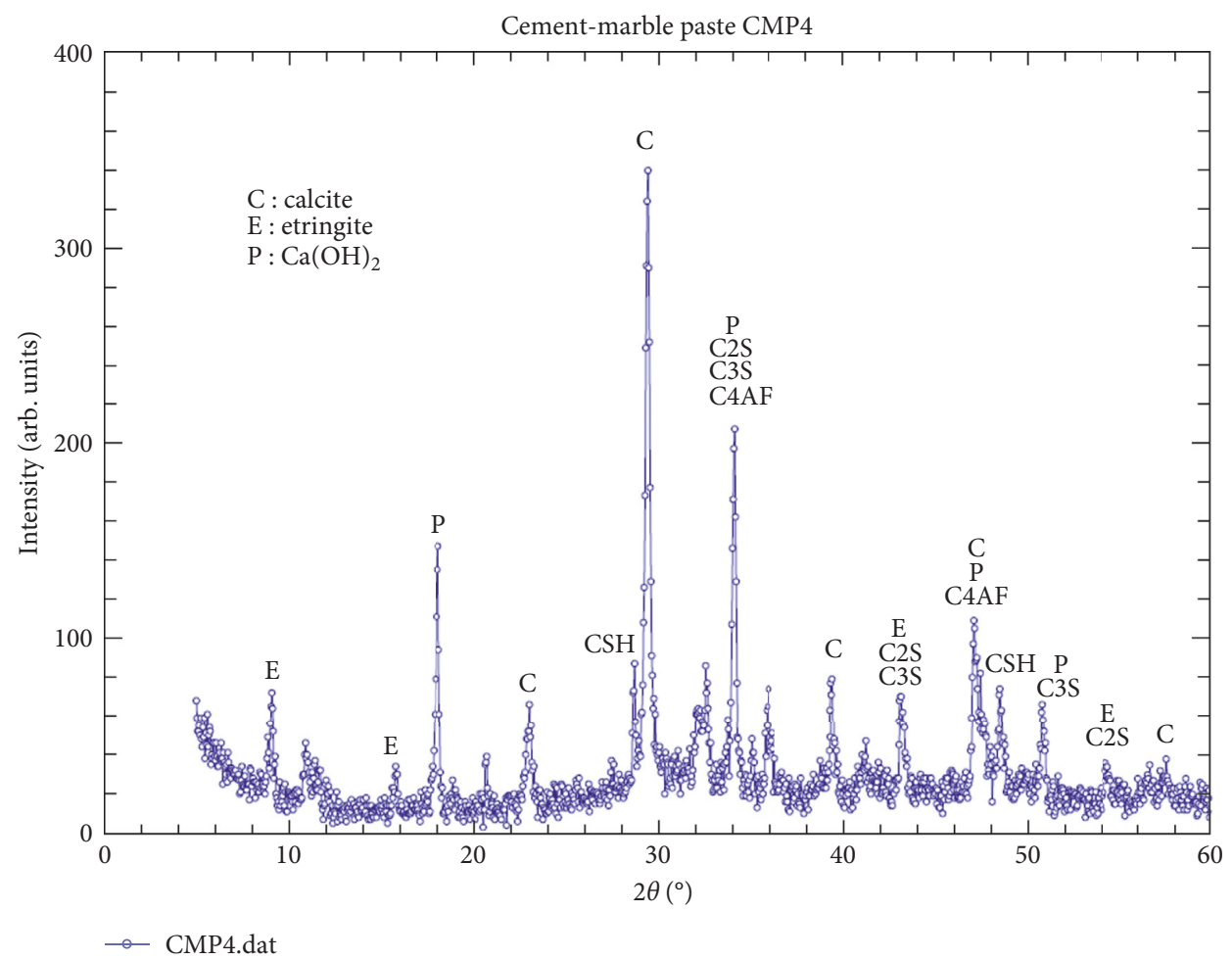

FIgURE 14: X-ray diffraction pattern of paste CMP4. 
refinement of the pore structure in SCC compared with ordinary concrete.

Indeed, the use of marble powder as a filler in the SCC composition increases intruded pore volume, reduces percentage of fine pores, and then increases compressive strength of the SCC. This confirms the obtained compressive strength values obtained for the concretes SCC1, SCC2, SCC3, and SCC4 (Table 8) because this strength is fundamentally a function of the distribution of the void space and porosity of concrete. According to the results of Table 8, the concrete SCC4, with high marble powder content, has a low compressive strength than the concrete SCC3 despite containing more marble powder than the second. This is due to the obtained segregation of this concrete which significantly decreases the compressive strength.

In addition, the rheological and the self-compaction properties of SCC will be improved with amount of MP. This confirms the obtained experimental data of slump test, flow time, bulk density, and L-box (Table 7).

\section{Conclusion}

The effects of the cement-MP paste volume on the SCC properties by a microstructure analysis were studied. The following conclusions can be drawn from the present work:

(i) The powder, obtained from the sludge of cutting marble blocks, can be used as a filler added to cementitious matrix of self-compacting concrete.

(ii) The cement-MP paste volume has a significant effect on rheological properties in fresh state of SCC and on its compressive strength.

(iii) There was a good correlation between fresh and hardened properties for the four SCCs with different cement-MP paste volume.

(iv) XRD patterns indicate that the large variation in chemical composition of marble powder paste does not affect the hydration process of the mix.

(v) SEM images show that the large adding amount of marble powder provides a mix with porous microstructures which affect the rheological properties and the compressive strength of SCC.

\section{Nomenclature}

SCC: Self-compacting concrete

MP: Marble sludge powder

MBV: Methylene blue value

BSS: Blaine specific surface $\left(\mathrm{cm}^{2} / \mathrm{g}\right)$

SP: $\quad$ Superplasticizer $(\mathrm{kg})$

F: $\quad$ Filler $(\mathrm{kg})$

S: $\quad$ Sand $(\mathrm{kg})$

C: $\quad$ Cement $(\mathrm{kg})$

W: $\quad$ Water $(\mathrm{kg})$

G: $\quad$ Gravel $(\mathrm{kg})$

A: $\quad$ Admixture $(\mathrm{kg})$

$V_{\mathrm{p}}$ : $\quad$ Volume of the paste $\left(\mathrm{m}^{3}\right)$

$\rho_{\mathrm{w}}$ : $\quad$ Density of water $\left(\mathrm{kg} / \mathrm{m}^{3}\right)$ $\rho_{\text {ad }}: \quad$ Density of admixture $\left(\mathrm{kg} / \mathrm{m}^{3}\right)$

$\left(\rho_{\text {abs }}\right)_{\mathrm{C}}:$ Absolute density of cement $\left(\mathrm{kg} / \mathrm{m}^{3}\right)$

$\left(\rho_{\mathrm{abs}}\right)_{\mathrm{F}}$ : Absolute density of filler $\left(\mathrm{kg} / \mathrm{m}^{3}\right)$.

\section{Data Availability}

The data used to support the findings of this study are available from the corresponding author upon request.

\section{Conflicts of Interest}

The authors declare that they have no conflicts of interest.

\section{Acknowledgments}

This project was supported by the Deanship of Scientific Research at Prince Sattam Bin Abdulaziz University under the research project No. 2017/01/7296.

\section{References}

[1] K. Vardhan, S. Goyal, R. Siddique, and M. Singh, "Mechanical properties and microstructural analysis of cement mortar incorporating marble powder as partial replacement of cement," Construction and Building Materials, vol. 96, pp. 615-621, 2015.

[2] H. Ş. Arel, "Recyclability of waste marble in concrete production," Journal of Cleaner Production, vol. 131, pp. 179-188, 2016.

[3] K. Esat and A. R. Ince, "A preliminary concrete mix design for SCC with marble powders," Construction and Building Materials, vol. 23, no. 3, pp. 1201-1210, 2009.

[4] İ. B. Topçu, T. Bilir, and T. Uygunoğlu, "Effect of waste marble dust content as filler on properties of self-compacting concrete," Construction and Building Materials, vol. 23, no. 5, pp. 1947-1953, 2009.

[5] A. S. E. Belaidi, L. Azzouz, E. Kadric, and S. Kenai, "Effect of natural pozzolana and marble powder on the properties of self-compacting concrete," Construction and Building Materials, vol. 31, pp. 251-257, 2012.

[6] D. Sadek, M. M. E. Attar, and H. A. Ali, "Reusing of marble and granite powders in self-compacting concrete for sustainable development," Journal of Cleaner Production, vol. 121, pp. 19-32, 2016.

[7] M. Gesoğlu, E. Güneyisi, M. E. Kocabağ, V. Bayram, and K. Mermerdaş, "Fresh and hardened characteristics of self compacting concretes made with combined use of marble powder, limestone filler, and fly ash," Construction and Building Materials, vol. 37, pp. 160-170, 2012.

[8] A. A. Aliabdo, A. E. M. A. Elmoaty, and E. M. Auda, "Re-use of waste marble dust in the production of cement and concrete," Construction and Building Materials, vol. 50, pp. 28-41, 2014.

[9] T. Uygunoğlu, İ. B. Topçu, and A. G. Çelik, "Use of waste marble and recycled aggregates in self-compacting concrete for environmental sustainability," Journal of Cleaner Production, vol. 84, pp. 691-700, 2014.

[10] W. Franus, R. Panek, and M. Wdowin, "SEM investigation of microstructures in hydration products of portland cement," in Proceedings of 2nd International Multidisciplinary Microscopy and Microanalysis Congress, pp. 105-112, Oludeniz, Turkey, October 2014. 
[11] T. Kavas and A. Olgun, "properties of cement and mortar incorporating marble dust and crushed brick," Ceramics-Silikáty, vol. 52, no. 1, pp. 24-28, 2008.

[12] R. S. Ahalya, N. Sakthieswaran, G. Shiny Brintha, and O. Ganesh Babu, "Microstructure analysis of cement mortar on partial replacement of fine aggregates by industrial wastes," International Journal for Research in Applied Science and Engineering Technology (IJRASET), vol. 4, no. 5, 2016.

[13] M. K. Maroliya, "Qualitative study of reactive powder concrete using X-ray diffraction technique," IOSR Journal of Engineering, vol. 2, no. 9, pp. 12-16, 2012.

[14] J. Elena and M. D. Lucia, "Application of X-ray diffraction (XRD) and scanning electron microscopy (SEM) methods to the portland cement hydration processes," Journal of Applied Engineering Sciences, vol. 2, no. 15, 2012.

[15] N. K. Dhapekar, A. S. Majumdar, and P. K. Gupta, "Study of phase composition of ordinary Portland cement concrete using X-ray diffraction," International Journal of Scientific and Engineering Research, vol. 6, no. 11, 2015.

[16] N. Ukrainczyk, M. Ukrainczyk, J. Šipušić, and T. Matusinović, "XRD and TGA investigation of hardened cement paste degradation," in Proceedings of conference on Conference on Materials, Processes, Friction and Wear, MATRIB'06, Vela Luka, Croatia, 2006.

[17] P. Nanthagopalan and M. Santhanam, "A simple and systematic mix design procedure for selfcompacting concrete," in Proceedings of 6th International RILEM Symposium on SCC, pp. 54-63, Montreal, Canada, 2010.

[18] M. Emborg, S. Gurnewald, C. Hedin, and J. Carlsward, "Test methods for filling ability of SCC," in Proceedings of $3 \mathrm{rd}$ International Symposium on Self-Compacting Concrete, pp. 323-334, Reykjavik, Iceland, 2003. 


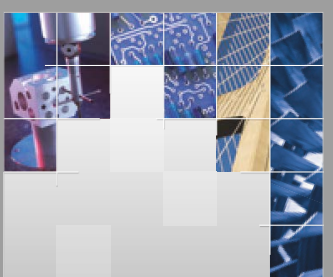

\section{Enfincering}
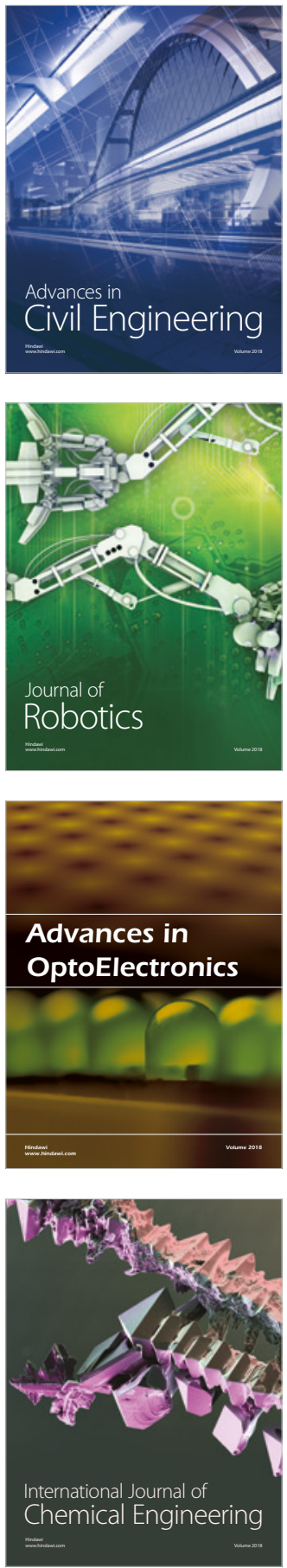

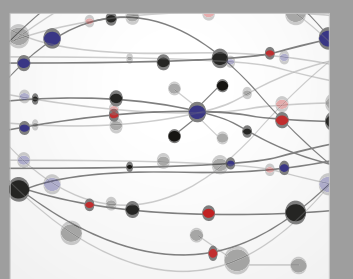

\section{Rotating \\ Machinery}

The Scientific World Journal

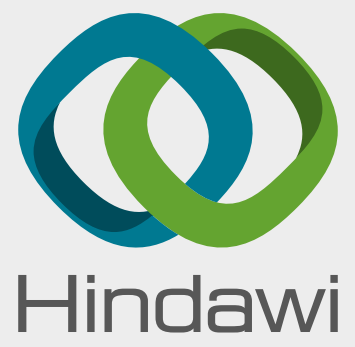

Submit your manuscripts at

www.hindawi.com
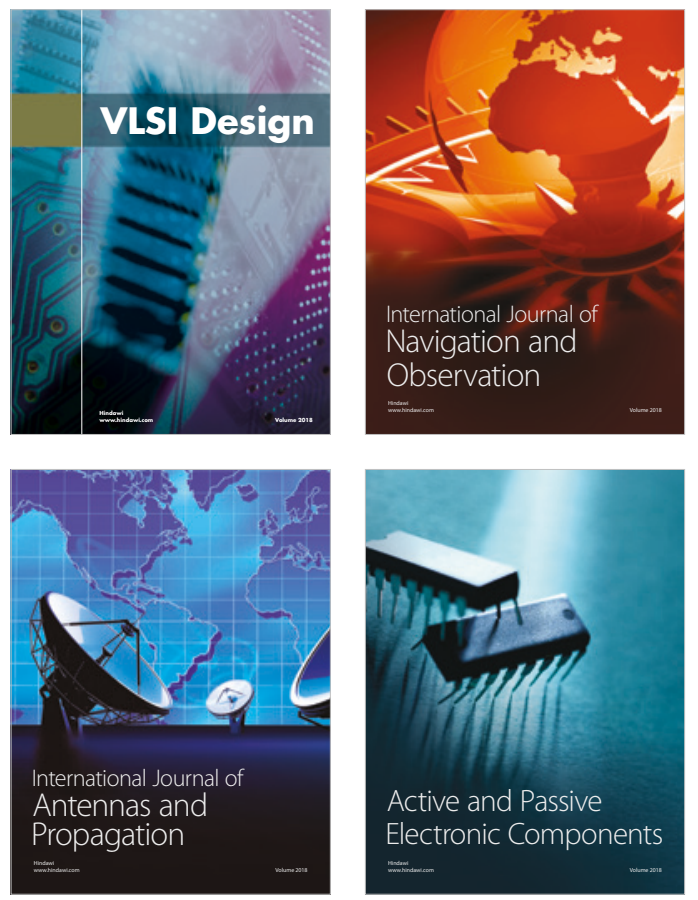
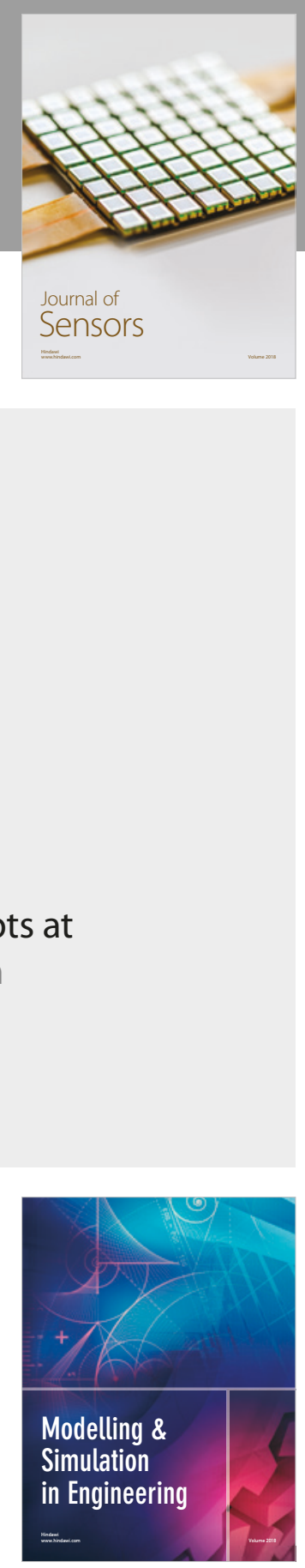

\section{Advances \\ Multimedia}
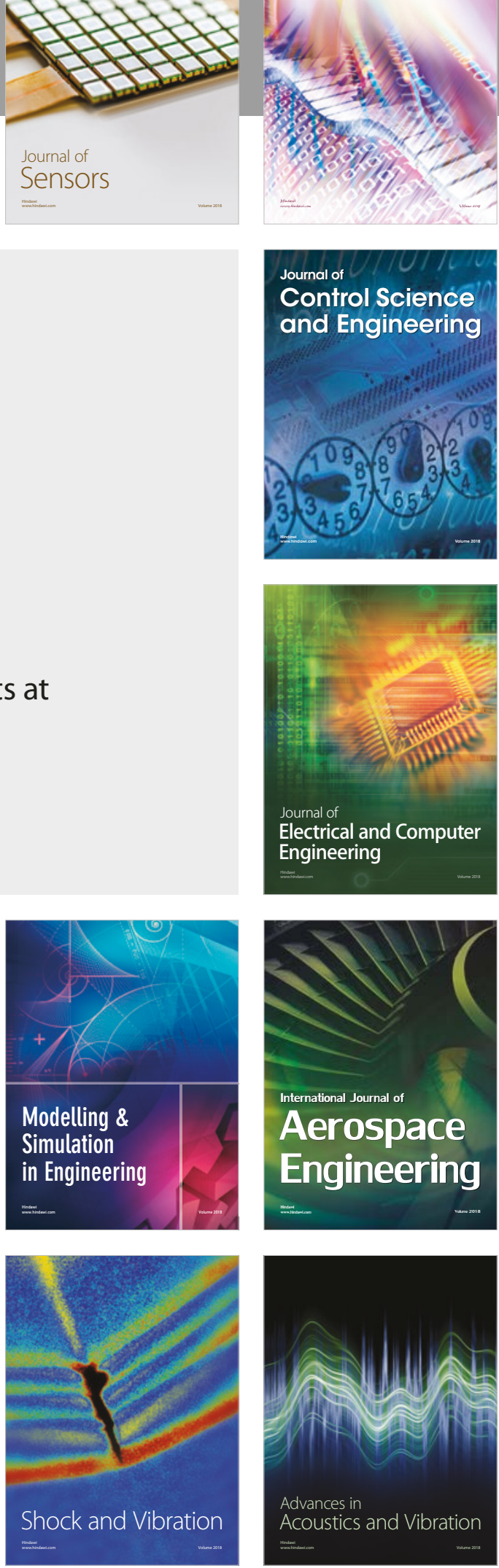